Article

\title{
Carbon and Nitrogen Content of Soil Organic Matter and Microbial Biomass under Long-Term Crop Rotation and Tillage in Illinois, USA
}

\author{
Stacy M. Zuber, Gevan D. Behnke, Emerson D. Nafziger and Maria B. Villamil * (iD \\ Department of Crop Sciences, University of Illinois, 1102 S. Goodwin Ave, Urbana, IL 61801, USA; \\ zuber0@purdue.edu (S.M.Z.); gbehnke2@illinois.edu (G.D.B.); ednaf@illinois.edu (E.D.N.) \\ * Correspondence: villamil@illinois.edu; Tel.: +1-217-333-4690
}

Received: 20 January 2018; Accepted: 8 March 2018; Published: 9 March 2018

\begin{abstract}
Crop rotation and tillage alter soil organic matter (SOM) dynamics by influencing the soil environment and microbes carrying out $\mathrm{C}$ and $\mathrm{N}$ cycling. Our goal was to evaluate the effect of long-term crop rotation and tillage on the quantity of $\mathrm{C}$ and $\mathrm{N}$ stored in SOM and microbial biomass. Two experimental sites were used to evaluate four rotations-continuous corn (Zea mays L.) (CCC), corn-soybean (Glycine max [L.] Merr.) (CS), corn-soybean-wheat (Triticum aestivum L.) (CSW), and continuous soybean (SSS), each split into chisel tillage (CT) and no-till (NT) subplots. The CSW rotation increased soil organic carbon (SOC) content compared to SSS; SSS also reduced total nitrogen (TN) compared to other rotations. Levels of SOC and TN were 7\% and $9 \%$ greater under NT than CT, respectively. Rotation did not affect microbial biomass $C$ and $N(M B C, M B N)$ while tillage reduced only MBN at 10-20 cm compared to NT, likely related to dispersion of N fertilizers throughout the soil. Despite the apparent lack of sensitivity of microbial biomass, changes in SOC and TN illustrate the effects of rotation and tillage on SOM dynamics. The inclusion of crops with high $\mathrm{C}: \mathrm{N}$ residues and no-till use both support higher $\mathrm{C}$ and $\mathrm{N}$ content in the top $20 \mathrm{~cm}$ of the soil.
\end{abstract}

Keywords: rotation; no-till; soil biology

\section{Introduction}

Crop rotation and tillage practices have a substantial influence on the soil as they alter the soil environment, influencing the habitat and energy source of the microbial community, the primary driver of SOM dynamics [1]. Microorganisms are responsible for the decomposition of organic matter inputs in the form of crop residues; as microbes break down residues, $\mathrm{C}$ becomes incorporated into microbial biomass, which becomes a key component of SOM [2]. The formation of soil aggregates are also directly related to microbial activity as microbial products are a binding agent within aggregates $[3,4]$. The microbial residues along with physically protected SOM within soil aggregates are resistant to degradation and contribute to the stability of SOM [1]. Agronomic practices play a substantial role in influencing the cycling of $\mathrm{C}$ through the soil and microbial community, yet environmental factors inherent to the soil and location, such as initial SOM levels, soil texture, and climate, will also affect the degree to which crop rotation and tillage influence SOM dynamics $[5,6]$.

A meta-analysis by McDaniel et al. [7] found that the addition of one or more crops to a monoculture increased the size of the microbial community as measured by both MBC and MBN, which are also related to the availability of resources and the favorability of the soil habitat. Beyond affecting soil microbes, the quantity and quality of residues returned to soil from a crop rotation can determine the amount of $\mathrm{C}$ and $\mathrm{N}$ stored within the SOM. Soil organic matter typically consists of $58 \%$ carbon, typically referred to as soil organic carbon [8]. The meta-analysis by McDaniel et al. [7] reported adding one or more crops into a crop rotation increases both SOC and soil total nitrogen (TN). In a global 
analysis of 67 studies, West and Post [9] also found that more complex rotations led to an accumulation of SOC across environments. However, both of these studies found that switching from continuous corn to a corn-soybean rotation was an exception that did not increase C. Higher biomass producing crops, such as corn, provide a larger pool of $C$ to return to the soil, but the rate of decomposition may be slower due to higher $\mathrm{C}: \mathrm{N}$ ratio of those residues $[7,10]$. The combination of greater residue production and slower decomposing residues of corn can lead to an accumulation of SOM in rotations that feature those crops more frequently compared to the reduced residue accumulation from soybean every other year from a corn-soybean rotation. Beyond just the residue input to the soil, the use of $\mathrm{N}$ fertilizers for crops such as corn and wheat affects the $\mathrm{N}$ within the soil as well as the soil $\mathrm{pH}$ [11]. Crop rotations that include legumes have lower biomass production and, as these legumes are typically grown without $\mathrm{N}$ fertilization, have been found to lead to lower TN and higher $\mathrm{pH}$ [12].

The role of tillage in the relationship between microbes and SOM is primarily through the impact of disturbance of the soil microclimate and the rate of decomposition of crop residues. The use of tillage increases aeration of the soil, reduces soil moisture content and leads to warmer soils in general $[13,14]$. Crop residues are fragmented into smaller pieces, increasing microbial access to residues accelerating the rate of decomposition [13]. In no-till (NT) soils, microbes are concentrated near the surface due to the proximity to crop residues; while in tilled soils, microbes and their activities are spread out to a greater depth as a result of the distribution of $C$ inputs throughout all of the disturbed soil layer [15]. A global meta-analysis of the effect of tillage to NT for microbial biomass reported reduced MBC and MBN under tillage compared to NT; however, this difference for MBC was found only for more intensive tillage practices as MBC under chisel tillage was similar to NT [16]. Reduced tillage not only leads to a larger microbial community, but can also lead to greater SOM compared to conventional tillage (CT), due to the slower decomposition rate of crop residues under NT [17]. Yet the exposure of SOM from within soil aggregates as the soil is disturbed by tillage may have a greater impact in the SOM differences reported for these systems. This physically-protected SOM decomposes when aggregates are disrupted by tillage, and these SOM losses are not offset by the $\mathrm{C}$ addition from crop residues [17]. Zuber et al. [12] reported greater SOC and TN under NT compared to CT on two Illinois soils after 15 years. The global analysis of West and Post [9] also reported that NT increased C sequestration substantially compared to tillage, and that this difference occurred primarily near the soil surface with $85 \%$ of the difference between tillage and no-till found in the top seven centimeters of the soil.

The high agricultural production of Illinois and the Midwestern U.S. relies on the fertile soils of the region; maintaining or improving productivity is a priority that will require maximizing the potential of these soils by selecting highly productive agronomic practices that also improve soil quality. The impact of SOC on numerous other soil properties, including water holding capacity and infiltration, nutrient availability, and soil structure, compel us to understand how SOM dynamics are influenced by agronomic practices. In Zuber et al. [12], we examined the effect of crop rotation and tillage on soil physical and chemical properties. In that study, crop rotation, specifically the frequency of soybean within the rotation, affected the TN and aggregate stability of the soil, but did not significantly influence the SOC. Due to the strong relationship between SOC and aggregate formation [4], it was surprising that the effect of rotations was greater on aggregate stability, but was not as evident for SOC. This discrepancy indicates that other aspects of the cycling of $C$ may be factors in the formation of aggregates and should be further investigated. Soil microbes are a vital component in SOM dynamics and microbial properties are considered to be more sensitive to environmental changes as shifts in microbial communities can occur much more rapidly than changes to chemical or physical soil properties [18]. Further work is needed to evaluate the influence of these agronomic practices on SOM dynamics, specifically their effect on microbial properties, such as MBC and MBN, and the relationship to SOC and TN content of the soils. We hypothesize that crop rotations with high $\mathrm{C}$ : $\mathrm{N}$ residues or greater biomass production, such as continuous corn (CCC) and corn-soybean-wheat (CSW), will lead to greater SOM and TN as well as microbial biomass as both MBC and MBN. Although 
a short corn-soybean (CS) rotation is more complex than continuous corn, we do not expect greater soil organic matter or microbial biomass, due to the reduced level of crop residues from soybean. It is expected that $\mathrm{SOC}, \mathrm{TN}$, and both $\mathrm{MBC}$ and $\mathrm{MBN}$ biomass will be greater for all rotations under no-till than conventional tillage in the top $20 \mathrm{~cm}$ of the soil.

The objectives of this study are to (1) evaluate effect of long-term crop rotation and tillage practices on SOC, TN, MBC, and MBN, and (2) determine the sensitivity of these soil properties to management practices and their ability to differentiate among different management practices after long-term use on two different highly productive Illinois soils, one a Mollisol and the other an Alfisol. Understanding the effect of crop rotation and tillage can benefit farmers throughout Illinois as they strive to maintain and protect their valuable soil resource and the high productivity of the region.

\section{Materials and Methods}

\subsection{Experimental Sites}

This study was conducted on two long-term crop rotation and tillage experimental studies initiated in 1996 (1) at the Northwestern Illinois Agricultural Research and Demonstration Center $\left(40^{\circ} 55^{\prime} 50^{\prime \prime} \mathrm{N}, 90^{\circ} 43^{\prime} 38^{\prime \prime} \mathrm{W}\right)$, near Monmouth, IL; and (2) at the Orr Agricultural Research and Demonstration Center $\left(39^{\circ} 48^{\prime} 4^{\prime \prime}\right.$ N, $\left.90^{\circ} 49^{\prime} 16^{\prime \prime} \mathrm{W}\right)$, near Perry, IL. At both locations, the experimental design was a split-plot arrangement of treatments rotation and tillage in a randomized complete block design with four replications. The main plot of crop rotation consisted of continuous corn (CCC), corn-soybean (CS), corn-soybean-wheat (CSW), and continuous soybean (SSS) with all crop phases of each rotation included. Each rotation was split into two levels of tillage: no-till (NT) and chisel tillage (CT). The tillage operations for CT consisted of fall primary tillage with a chisel plow to a depth of 20- to $25-\mathrm{cm}$ and secondary spring tillage with a field cultivator prior to planting. Each main plot was $22 \mathrm{~m}$ long by $12 \mathrm{~m}$ wide, and sub-plots were $22 \mathrm{~m}$ long by $6 \mathrm{~m}$ wide. Further descriptions of the management practices are reported in Zuber et al. [12].

Soils series at Monmouth are Sable silty clay loam (Fine-silty, mixed, mesic Typic Endoaquolls) and Muscatune silt loam (Fine-silty, mixed, mesic Aquic Argiudolls), with about $10 \%$ of the study area on Osco silt loam (Fine-silty, mixed, superactive, mesic Typic Argiudolls). These soils are dark-colored and very deep with a slope of less than $2 \%$, developed in loess 2-3 m thick over till under prairie vegetation. All three soils are moderately permeable. While Sable and Muscatune are poorly drained and somewhat poorly drained, respectively, Osco soils are well drained [19]. The mean annual temperature at the site is $10.9{ }^{\circ} \mathrm{C}$ with mean annual precipitation of $1000 \mathrm{~mm}$. Experimental plots at Perry are primarily located on Downsouth silt loam (Fine-silty, mixed, mesic Mollic Oxyaquic Hapludalfs) and Caseyville silt loam (Fine-silty, mixed, mesic Aeric Endoaqualfs) soils with slope of less than $2 \%$. Both consist of very deep, moderately well drained soils with moderate permeability formed in 1-3 m loess over till under mixed prairie and forest vegetation [19]. The mean annual temperature at the site is $11.1^{\circ} \mathrm{C}$ with mean annual precipitation of $1002 \mathrm{~mm}$.

\subsection{Soil Analyses}

Soil samples were collected in May 2014 at Monmouth and in May 2015 at Perry; experimental plots were established in 1996 at both locations. Samples were collected using an Amity 4804 tractormounted hydraulic probe (Amity Technology, Fargo, ND, USA) to take three soil cores $4.3 \mathrm{~cm}$ in diameter in each subplot. Soil cores were cut to $0-10$ and $10-20 \mathrm{~cm}$ depths. The soil samples were air-dried and sieved through 2-mm sieve, and the three subsamples from each plot were composited to provide one sample per plot. Soil organic carbon and TN were analyzed using dry combustion using an automated CHN analyzer [20,21] at a commercial laboratory (Brookside Laboratories, Inc., New Bremen, $\mathrm{OH}, \mathrm{USA})$. Microbial biomass $\mathrm{C}(\mathrm{MBC})$ and $\mathrm{N}(\mathrm{MBN})$ were determined using a modified version of chloroform fumigation extraction protocol from Rice et al. [22]. Due to the large number of soil samples and the time required for processing, the protocol was modified to use air-dried soil 
samples. Both fumigated and unfumigated soil samples were rewet to approximately $50 \%$ of field capacity for $24 \mathrm{~h}$ prior to fumigation or extraction, respectively [23]. Soil samples were fumigated for $48 \mathrm{~h}$ with chloroform before extraction with $0.5 \mathrm{M} \mathrm{K}_{2} \mathrm{SO}_{4}$. Microbial biomass extracts were analyzed for organic $\mathrm{C}$ and total $\mathrm{N}$ on Shimadzu TOC-L and TNM-L analyzer (Shimadzu Corporation, Kyoto, Japan). Microbial biomass was calculated as the difference in $\mathrm{C}$ or $\mathrm{N}$ between the fumigated and unfumigated samples according to standard protocol. Due to the use of air-dried samples, MBC and MBN values will only be used to as comparative values rather than as actual size of the microbial biomass; therefore, a conversion factor was not used to scale microbial biomass as is recommended in the literature [22].

\subsection{Statistical Analyses}

Data analysis was conducted using GLIMMIX procedure of SAS version 9.4 (SAS Institute Inc., Cary, NC, USA). Rotation, tillage, crop phase nested within rotation, depth, and their interactions were considered fixed effects, and blocks and sites were considered random. Depth was analyzed using a repeated measures approach with the variance-covariance structure of ar(1), autoregressive, or arh(1), heterogeneous autoregressive, selected for each variable based on the Akaike's Information Criterion [24]. Random interactions with site were tested for significance using -2log likelihood values, and terms that were not significant were removed from the model. A lognormal distribution (dist = logn) was used for MBC and MBN due to the lack of normality of the model residuals. Least square means were separated using LSMEANS and LINES option within GLIMMIX using a Tukey adjustment with $\alpha=0.10$. When the crop phase was found to be significant, estimate statements were used to test for differences among crops within a specific rotation. Statistical model and code is available upon request from the authors.

\section{Results and Discussion}

Soil organic carbon was significantly affected by rotation (Table 1). The CSW rotation led to greater SOC levels compared to SSS; however, CS and CCC were intermediate and not significantly different from either CSW or SSS (Table 2). The greater SOC under CSW is probably related to the slower decomposition rate of the high $\mathrm{C}: \mathrm{N}$ ratio corn and wheat residues compared to the soybean residues. Similarly, Van Eerd et al. [25], reported that the inclusion of winter wheat in a corn-soybean rotation led to greater SOC in two long-term ( $>10$ years) experiments in Ontario, Canada under both NT and CT. Van Eerd et al. [25], attributed the greater SOC with high frequency wheat crop rotations, in part to the greater lignin found in wheat residues, which is recalcitrant and would slow decomposition. The discrepancy in biomass decomposition among crops also leads to the expectation of greater SOC under CCC compared to CS as reported in a large-scale data analysis by West and Post [9]; however, no differences were found between CCC and CS within this study. Similar results were reported by Kumar et al. [6] who compared CCC and CS under different tillage practices on two contrasting soils in Ohio.

Table 1. Probability values associated with the analysis of variance of the effects across two sites of rotation, tillage, and depth and their interactions on soil organic carbon (SOC), total nitrogen (TN), microbial biomass $\mathrm{C}(\mathrm{MBC})$, and microbial biomass $\mathrm{N}(\mathrm{MBN})$.

\begin{tabular}{ccccc}
\hline Source & SOC & TN & MBC & MBN \\
\hline Rotation (R) & 0.057 & 0.001 & 0.557 & 0.507 \\
Tillage (T) & 0.072 & 0.021 & 0.249 & 0.112 \\
R $\times$ T & 0.550 & 0.319 & 0.819 & 0.358 \\
Depth (D) & 0.001 & 0.352 & $<0.0001$ & $<0.0001$ \\
R $\times$ D & 0.590 & 0.117 & 0.600 & 0.363 \\
T $\times$ D & 0.074 & 0.001 & 0.098 & 0.086 \\
$\mathrm{R} \times \mathrm{T} \times \mathrm{D}$ & 0.901 & 0.669 & 0.267 & 0.339 \\
\hline
\end{tabular}


Table 2. Mean values and standard errors (SE) of soil organic carbon (SOC) and total nitrogen (TN) across two sites with rotation and tillage.

\begin{tabular}{|c|c|c|c|c|c|c|c|c|c|c|c|c|c|}
\hline \multirow[b]{4}{*}{ Rotation } & \multirow[b]{4}{*}{ Tillage } & \multicolumn{6}{|c|}{ Depth (cm) } & \multicolumn{6}{|c|}{ Depth (cm) } \\
\hline & & \multicolumn{2}{|c|}{ 0-10 } & \multicolumn{2}{|c|}{$10-20$} & \multicolumn{2}{|c|}{$0-20$} & \multicolumn{2}{|l|}{ 0-10 } & \multicolumn{2}{|c|}{$10-20$} & \multicolumn{2}{|c|}{$0-20$} \\
\hline & & \multicolumn{6}{|c|}{$\operatorname{SOC}\left(\mathrm{g} \mathrm{kg}^{-1}\right)$} & \multicolumn{6}{|c|}{$\mathrm{TN}\left(\mathrm{g} \mathrm{kg}^{-1}\right)$} \\
\hline & & Mean & SE & Mean & SE & Mean & SE & Mean & SE & Mean & SE & Mean & SE \\
\hline \multirow{2}{*}{$\mathrm{CCC}^{*}$} & $\mathrm{CT}$ & 19.8 & 6.4 & 17.3 & 6.3 & 18.5 & 6.3 & 1.83 & 0.31 & 1.57 & 0.13 & 1.70 & 0.17 \\
\hline & NT & 22.2 & & 18.3 & & 20.2 & & 2.03 & & 1.62 & & 1.82 & \\
\hline \multirow{2}{*}{ CS } & $\mathrm{CT}$ & 19.2 & & 17.3 & & 18.3 & & 1.81 & & 1.50 & & 1.65 & \\
\hline & NT & 21.7 & & 17.1 & & 19.4 & & 2.37 & & 1.50 & & 1.94 & \\
\hline \multirow{2}{*}{ CSW } & $\mathrm{CT}$ & 21.4 & & 19.2 & & 20.3 & & 2.04 & & 1.65 & & 1.84 & \\
\hline & NT & 23.2 & & 18.2 & & 20.7 & & 2.05 & & 1.55 & & 1.80 & \\
\hline \multirow{2}{*}{ SSS } & $\mathrm{CT}$ & 16.8 & & 16.2 & & 16.5 & & 1.39 & & 1.38 & & 1.38 & \\
\hline & NT & 20.1 & & 17.7 & & 18.6 & & 1.78 & & 1.46 & & 1.62 & \\
\hline CCC & & 21.0 & 6.4 & 17.8 & 6.4 & $19.4 \mathrm{AB}^{\S}$ & 6.3 & 1.93 & 0.23 & 1.60 & 0.13 & $1.76 \mathrm{~A}$ & 0.14 \\
\hline CS & & 20.5 & & 17.2 & & $18.8 \mathrm{AB}$ & & 2.09 & & 1.50 & & $1.80 \mathrm{~A}$ & \\
\hline CSW & & 22.3 & & 18.7 & & $20.5 \mathrm{~A}$ & & 2.04 & & 1.60 & & $1.82 \mathrm{~A}$ & \\
\hline \multirow[t]{3}{*}{ SSS } & & 18.4 & & 16.6 & & $17.5 \mathrm{~B}$ & & 1.58 & & 1.42 & & $1.50 \mathrm{~B}$ & \\
\hline & $\mathrm{CT}$ & $19.3 b^{t, \neq}$ & 6.3 & $17.5 \mathrm{~b}$ & 6.3 & $18.4 \mathrm{~B}$ & 6.3 & $1.76 \mathrm{~b}$ & 0.17 & $1.52 \mathrm{ab}$ & 0.12 & $1.64 \mathrm{~B}$ & 0.11 \\
\hline & NT & $21.8 \mathrm{a}$ & & $17.7 \mathrm{~b}$ & & $19.7 \mathrm{~A}$ & & $2.06 \mathrm{a}$ & & $1.53 \mathrm{ab}$ & & $1.79 \mathrm{~A}$ & \\
\hline
\end{tabular}

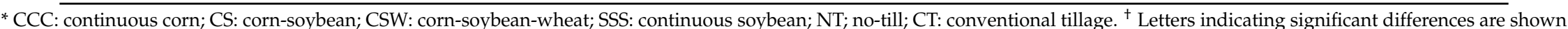
only for significant effects $(\alpha=0.10)$. ${ }^{\ddagger}$ Within a combination of factors, means for a specific variable followed by the same lowercase letter are not significantly different $(\alpha=0.10)$. $\$$ Within a column and factor, means averaged over depths followed by the same uppercase letter are not significantly different $(\alpha=0.10)$. 
While no differences in SOC were found between CCC and CS, SOC differed by the crop phases within the short CS rotation with greater SOC in the corn phase $\left(19.8 \mathrm{~g} \mathrm{~kg}^{-1}\right)$ compared to soybean $\left(17.9 \mathrm{~g} \mathrm{~kg}^{-1}\right)$ (Figure 1).
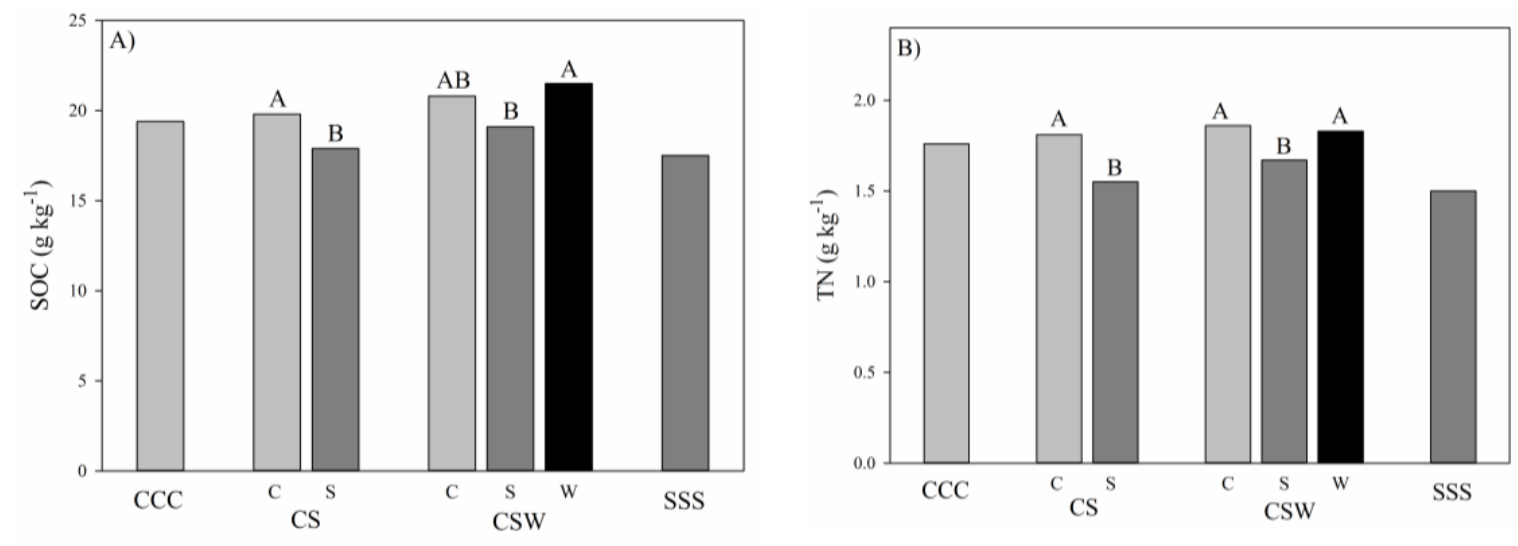

Figure 1. Effect of crop phase (C: corn; S: soybean; W: wheat) within rotations of continuous corn (CCC), corn-soybean (CS), corn-soybean-wheat (CSW) and continuous soybean (SSS) on (A) soil organic carbon (SOC) and (B) total nitrogen (TN) across two sites for 0-20 cm soil depth. Within a crop rotation, bars with the same letter are not significantly different at $\alpha=0.10$.

These soils were sampled in late spring; therefore, nitrogen fertilizer had been applied and the current crop had already been planted at the time of sampling. The greater SOC under corn cannot be due to greater biomass from the soybean of the previous year, but is probably related to the relatively rapid decomposition of the soybean residues from the previous year that were already incorporated into the SOC. In contrast, the soils from the soybean phase had greater biomass from the previous year's corn crop, but it is likely those were only partially decomposed due to the slow decomposition of high C: $N$ ratio corn residues $[26,27]$. As any pieces of litter were removed as much as possible during the sieving process $(<2 \mathrm{~mm})$ prior to analysis for SOC, these corn residues would have not contributed much to the amount of SOC measured. Beyond this, it is possible that the corn residues induced positive priming, wherein the addition of fresh residues stimulates microbial activity and increases SOM decomposition rates $[26,28,29]$ with high $\mathrm{C}: \mathrm{N}$ ratio residues, such as corn, have a stronger effect than lower $\mathrm{C}: \mathrm{N}$ ratio residues [30]. These possible explanations are further supported by the differences among crop phases of the CSW rotation. In contrast to CS rotation, the SOC of the corn $\left(20.8 \mathrm{~g} \mathrm{~kg}^{-1}\right)$ and soybean phases $\left(19.1 \mathrm{~g} \mathrm{~kg}^{-1}\right)$ did not differ within CSW; however, the SOC was greater during the wheat phase $\left(21.5 \mathrm{~g} \mathrm{~kg}^{-1}\right)$ compared to the soybean phase. In both CS and CSW, the SOC of the crop phase immediately following soybean was greater than the SOC measured following corn. This difference between crop phases likely indicates that SOC levels are not as steady as expected from year to year under long-term management due to either or both a flush of SOC following soybean or a decrease in SOC following corn due to the priming effect. This fluctuation may serve as a partial explanation of the failure to detect differences between CCC and CS.

As with SOC, rotation had a statistically significant effect on TN (Table 1) with $16 \%$ less soil TN under SSS than the corn-based rotations (Table 2). Soybean within a rotation has been found to lead to decrease TN $[12,31,32]$. During the corn and wheat phases, $\mathrm{N}$ fertilizer is applied to supplement the plant available $\mathrm{N}$ from the soil. Of the $\mathrm{N}$ taken up by the plant, approximately $64 \%$ for corn [33] and $70 \%$ for wheat [34] is removed with the grain at harvest. The remainder of the $\mathrm{N}$ is returned to the soil and often immobilized within SOC due to the high C: $\mathrm{N}$ ratios of those residues [35]. This would probably lead to a subsequent increase in TN. However, the difference between the corn-based rotations and SSS may be more complex as it could be also related to a decrease in TN from the continuous soybean cropping. Soybean is a net $\mathrm{N}$ user leading to depletion of soil $\mathrm{N}$ after continuous usage [36]. Ultimately, it is likely that TN decreased under SSS, but it is difficult to determine if TN increased in 
the corn-based rotations as a result of $\mathrm{N}$ fertilizer inputs or rather was maintained to previous levels. It is also possible that there was a loss of TN in all rotations but to a lesser degree in those with corn. As there were no baseline levels measured on these experimental plots at the time of establishment, the answer to that query is beyond the scope of this study. Despite no differences among the three corn-based rotations, there were significant difference between the crop phases within CS and within CSW (Figure 1). For each of these rotations, TN was greater during the crop phase following soybean than following corn, similar to the pattern measured for SOC. Unlike SOC, TN was not significantly different between depths, but this is likely related to the significant site $\times$ depth random interaction, which indicates that the differences between depths varied at the two sites. This may be due to differences in timing of sampling or $\mathrm{N}$ fertilization.

Greater levels of both SOC and TN were found under NT than CT in the surface $10 \mathrm{~cm}$. Despite tillage disturbance occurring to the depth of $20-25 \mathrm{~cm}$, there were no significant differences between NT and CT in the 10-20 cm soil depth. As residues are added to the soil surface while the soil is undisturbed, NT practices can lead to greater SOC and TN than in tilled soils $[9,25,31,37]$. As in this study, the difference between NT and CT for SOC and other nutrients has often been reported only in the surface soils [5,38]. Our previous work, Zuber et al. [12], examined both soil physical and chemical properties, including SOC and TN, and found that $C$ and $N$ stocks to a depth of $60 \mathrm{~cm}$ were greater in NT compared to CT when measured two years prior to this study.

Soil organic matter dynamics are highly dependent on microbial communities as the stable form of SOM is a product of microbial decomposition [39,40]. Microbial biomass can provide an indirect indication about how the size of a microbial community is affected by agronomic practices. Within our study, there were no differences among crop rotations for either MBC or MBN (Table 1). In contrast, McDaniel et al. [7] conducted a global meta-analysis evaluating the effect of crop rotation on microbial biomass and reported large increases in both MBC (20.7\%) and MBN $(26.1 \%)$ with a rotation compared to the use of a single crop regardless of the number of crops within the rotation. Within the Midwestern USA, studies by Russell et al. [41], and Ekenler and Tabatabai [42], both in Iowa, reported greater MBC within a crop rotation compared to a no rotation of crops, which is likely related to the greater diversity of organic matter inputs from a rotation that would stimulate microbial community growth. However, the crop rotation that resulted in increased MBC was more complex than those in our study and included oats and alfalfa. When comparing CCC and CS, Russell et al. [41] reported greater MBC under CCC than under CS, indicating that the short CS rotation did not augment microbial community size. The lack of differences among rotation for $\mathrm{MBC}$ and $\mathrm{MBN}$ in our study may indicate that the increase in diversity of residues by including other crops within the rotation is offset by the decrease in biomass available to microbes or differences in the residue quality, especially following the soybean phase of the rotation.

Tillage had a greater influence on microbial biomass than crop rotation as the interaction effect of tillage by depth was significant for both MBC and MBN at $\alpha=0.10$ (Table 1). There was a trend of greater MBC under NT compared to CT at the surface $10 \mathrm{~cm}$ (Tables 3 and 4); however, this should be considered with caution as when adjusted with Tukey's for multiple comparisons, this difference was not significant. Despite the tillage depth of 20-25 cm, which encompassed the entire measured layer of soil, there was no significant difference below $10 \mathrm{~cm}$ between the undisturbed NT soil and the tilled soil with crop residues dispersed throughout. 
Table 3. Mean values and standard errors (SE) of natural logarithm transformed microbial biomass $\mathrm{C}(\mathrm{MBC})$ across two sites as affected by rotation and tillage. Backtransformed means are shown in parentheses in units of $\mathrm{mg} \mathrm{kg}^{-1}$.

\begin{tabular}{|c|c|c|c|c|c|c|c|}
\hline \multirow[b]{3}{*}{ Rotation } & \multirow[b]{3}{*}{ Tillage } & \multicolumn{6}{|c|}{ Depth (cm) } \\
\hline & & \multicolumn{2}{|l|}{ 0-10 } & \multicolumn{2}{|c|}{$10-20$} & \multicolumn{2}{|c|}{$0-20$} \\
\hline & & Mean & SE & Mean & SE & Mean & SE \\
\hline \multirow{2}{*}{$\mathrm{CCC}^{*}$} & $\mathrm{CT}$ & $3.75(42.7)$ & 0.31 & $3.32(27.6)$ & 0.31 & $3.53(34.3)$ & 0.28 \\
\hline & NT & $4.12(61.5)$ & 0.31 & $3.43(30.8)$ & 0.31 & 3.77 (43.5) & 0.28 \\
\hline \multirow{2}{*}{ CS } & $\mathrm{CT}$ & $4.02(55.5)$ & 0.28 & $3.57(35.4)$ & 0.28 & $3.79(44.3)$ & 0.26 \\
\hline & NT & 4.37 (79.3) & 0.28 & $3.61(36.8)$ & 0.28 & $3.99(54.0)$ & 0.26 \\
\hline \multirow{2}{*}{ CSW } & $\mathrm{CT}$ & $4.12(61.6)$ & 0.27 & $3.29(26.9)$ & 0.27 & $3.71(40.7)$ & 0.26 \\
\hline & NT & $4.23(68.6)$ & 0.27 & $3.52(33.7)$ & 0.27 & 3.87 (48.1) & 0.26 \\
\hline \multirow{2}{*}{ SSS } & $\mathrm{CT}$ & $4.13(61.9)$ & 0.31 & $3.66(39.0)$ & 0.31 & $3.89(49.1)$ & 0.28 \\
\hline & NT & $4.31(74.7)$ & 0.31 & $3.32(27.8)$ & 0.31 & $3.82(45.6)$ & 0.28 \\
\hline CCC & & 3.94 (51.2) & 0.27 & $3.37(29.1)$ & 0.27 & $3.65(38.6)$ & 0.25 \\
\hline CS & & $4.19(66.3)$ & 0.25 & $3.59(36.1)$ & 0.25 & $3.89(48.9)$ & 0.24 \\
\hline CSW & & $4.17(65.0)$ & 0.24 & $3.40(30.1)$ & 0.24 & $3.79(44.3)$ & 0.24 \\
\hline \multirow[t]{3}{*}{ SSS } & & $4.22(68.0)$ & 0.27 & 3.49 (32.9) & 0.27 & $3.86(47.3)$ & 0.25 \\
\hline & $\mathrm{CT}$ & $4.00(54.8) \mathrm{a}^{t, \ddagger}$ & 0.24 & $3.46(31.8) b$ & 0.24 & $3.73(41.8)$ & 0.23 \\
\hline & NT & $4.26(70.7)$ a & 0.24 & $3.47(32.1) b$ & 0.24 & $3.86(47.6)$ & 0.23 \\
\hline
\end{tabular}

* CCC: continuous corn; CS: corn-soybean; CSW: corn-soybean-wheat; SSS: continuous soybean; NT: no-till; CT: conventional tillage. ${ }^{\dagger}$ Letters indicating significant differences are shown only for significant effects $(\alpha=0.10)$. $\ddagger$ Within a combination of factors, means followed by the same lowercase letter are not significantly different $(\alpha=0.10)$.

Table 4. Mean values and standard errors (SE) of natural logarithm transformed microbial biomass $\mathrm{N}(\mathrm{MBN})$ across two sites as affected by rotation and tillage. Backtransformed means are shown in parentheses in units of $\mathrm{mg} \mathrm{kg}^{-1}$.

\begin{tabular}{|c|c|c|c|c|c|c|c|}
\hline \multirow[b]{3}{*}{ Rotation } & \multirow[b]{3}{*}{ Tillage } & \multicolumn{6}{|c|}{ Depth (cm) } \\
\hline & & \multicolumn{2}{|l|}{ 0-10 } & \multicolumn{2}{|c|}{ 10-20 } & \multicolumn{2}{|c|}{$0-20$} \\
\hline & & Mean & SE & Mean & SE & Mean & SE \\
\hline \multirow{2}{*}{$\mathrm{CCC}^{*}$} & $\mathrm{CT}$ & $1.80(6.04)$ & 0.36 & $0.61(1.85)$ & 0.29 & $1.21(3.34)$ & 0.28 \\
\hline & NT & $1.86(6.43)$ & 0.36 & $1.68(5.37)$ & 0.28 & $1.77(5.87)$ & 0.27 \\
\hline \multirow{2}{*}{ CS } & $\mathrm{CT}$ & $2.19(8.94)$ & 0.27 & $1.54(4.67)$ & 0.22 & $1.87(6.46)$ & 0.22 \\
\hline & NT & $2.06(7.86)$ & 0.27 & $1.51(4.52)$ & 0.21 & 1.79 (5.96) & 0.21 \\
\hline \multirow{2}{*}{ CSW } & $\mathrm{CT}$ & $2.10(8.14)$ & 0.23 & 1.37 (3.94) & 0.19 & $1.73(5.66)$ & 0.19 \\
\hline & NT & $2.04(7.66)$ & 0.23 & $1.61(4.98)$ & 0.19 & $1.82(6.18)$ & 0.19 \\
\hline \multirow{2}{*}{ SSS } & $\mathrm{CT}$ & $2.17(8.73)$ & 0.36 & $1.13(3.11)$ & 0.28 & $1.65(5.21)$ & 0.27 \\
\hline & NT & $2.66(14.28)$ & 0.36 & $1.60(4.97)$ & 0.28 & $2.13(8.43)$ & 0.27 \\
\hline $\mathrm{CCC}$ & & $1.83(6.23)$ & 0.27 & $1.15(3.15)$ & 0.22 & $1.49(4.43)$ & 0.21 \\
\hline CS & & $2.13(8.38)$ & 0.21 & $1.52(4.59)$ & 0.18 & $1.83(6.21)$ & 0.17 \\
\hline CSW & & $2.07(7.90)$ & 0.19 & $1.49(4.43)$ & 0.16 & $1.78(5.92)$ & 0.16 \\
\hline \multirow[t]{3}{*}{ SSS } & & 2.41 (11.17) & 0.27 & 1.37 (3.93) & 0.21 & $1.89(6.62)$ & 0.21 \\
\hline & $\mathrm{CT}$ & $2.06(7.87) \mathrm{a}^{+, \ddagger}$ & 0.17 & $1.16(3.20) \mathrm{C}$ & 0.14 & $1.61(5.02)$ & 0.14 \\
\hline & NT & 2.15 (8.62) a & 0.17 & $1.60(4.95) b$ & 0.14 & $1.88(6.53)$ & 0.14 \\
\hline
\end{tabular}

* CCC: continuous corn; CS: corn-soybean; CSW: corn-soybean-wheat; SSS: continuous soybean; NT: no-till; CT: conventional tillage. ${ }^{\dagger}$ Letters indicating significant differences are shown only for significant effects $(\alpha=0.10)$. $\ddagger$ Within a combination of factors, means followed by the same lowercase letter are not significantly different $(\alpha=0.10)$. 
For MBN, there was no difference between tillage practices at the surface, but from 10 to $20 \mathrm{~cm}$ MBN was greater in NT than CT. These results are rather unexpected as the meta-analysis by Zuber and Villamil [16] reported greater MBC and MBN with NT compared to tillage. However, the difference between NT and tillage was minimal for MBC when the tillage implement was a chisel plow, such as was used in this study. For MBN, as with SOM and TN, we would expect that any difference between tillage practices would occur at the surface. In this case, the opposite result was found as MBN was greater with NT than with CT at the $10-20 \mathrm{~cm}$ depth. However, for most of the crop rotations, MBN was similar between CT and NT at both $0-10 \mathrm{~cm}$ and 10-20 cm depths. The exception to this was CCC, which had MBN at 10-20 cm depth of $1.85 \mathrm{mg} \mathrm{kg}^{-1}$ under CT while the other three rotations averaged $5.75 \mathrm{mg} \mathrm{kg}^{-1}$. While the high $\mathrm{C}$ : $\mathrm{N}$ ratio corn residues in this soil would be expected to lead to a net immobilization as $\mathrm{N}$ is incorporated by microbes, the addition of $\mathrm{N}$ fertilizer would likely have increased mineralization. The $\mathrm{N}$ would have been incorporated into microbial cells as the microbial extracellular and intracellular enzyme broke down the residues. Following the augmentation of microbial biomass, microbe predation would subsequently increase, releasing plant-available $\mathrm{N}$ and reducing MBN; this is similar to the microbial loop process following the release of root exudates into the rhizosphere $[43,44]$. Microbial metabolism as well as microbial stress and death would also release immobilized $N[44,45]$ and could have led to the reduction in MBN found in our study under tilled CCC. However, this result could be related to shifts in the microbial community or simply an outlier due to spatial variability.

The lack of significant differences among rotations and the relatively low significance of tillage by depth both indicate a surprising lack of sensitivity of microbial biomass to crop rotation and tillage. Microbial biomass, like most biological properties, is highly variable and as a result of sensitivity to environmental conditions, fluctuates seasonally [46]. It is possible that at the time of sampling the MB was similar regardless of rotation or tillage, but later changed as a result of root exudates, temperature, or precipitation so a different timing of sampling could have led to more expected results. A shallower sampling depth for the top layer may have also been more likely to yield significant differences between tillage practices on the soil surface.

\section{Conclusions}

The impact of crop rotation on SOC and TN in two Illinois soils was relatively minor, as differences in SOC were found only between CSW and SSS while SSS also led to less TN compared to the corn-based rotations. Thus, the inclusion of high $\mathrm{C}: \mathrm{N}$ ratio residues (corn or wheat) within a rotation help to maintain both $\mathrm{C}$ and $\mathrm{N}$ storage within SOM, but in comparison between different crop sequences, the frequency of these crops within the rotation only minimally affects the levels of SOC and TN. Rather, it is the specific phase within the rotation that is an important factor that should be considered when comparing different crop rotations. The reduced SOC and TN measured during the growing season following corn indicates that, even 17 years after establishment, there are seasonal fluctuations within SOM that affects our ability to detect differences among rotations. On the other hand, tillage had a clear impact on SOM as the use of no-till practices led to $7 \%$ and $9 \%$ greater SOC and TN, respectively, compared to tillage. While tillage and, to a lesser degree, rotation, both influenced the storage of $\mathrm{C}$ and $\mathrm{N}$ within SOM, their effect on the microbial community was not as clear. Despite the purported sensitivity of biological properties such as microbial biomass, these soil parameters were relatively stable among crop rotation and tillage practices on highly productive Illinois soils. High variability in these measures is likely an important component of the lack of differences. While microbial biomass provides a snapshot of the community size, more in-depth evaluation of the structure and diversity of the microbes may reveal how crop rotation and tillage influence the community in other ways. 
Acknowledgments: Funding was provided by USDA-NIFA, award no. 2011-68002-30190 “Cropping Systems Coordinated Agricultural Project (CSCAP): Climate Change, Mitigation, and Adaptation in Corn-based Cropping Systems" as part of a regional collaborative project led by L. Morton (www.sustainablecorn.org). We acknowledge the contributions of Mike Vose, Marty Johnson, Eric Adee, and Brian Mansfield in initiating and managing the field trials at Perry and Monmouth.

Author Contributions: M.B.V. and E.D.N. conceived and designed the experiments and contributed reagents/ materials/analysis tools; S.M.Z. and G.D.B. performed the experiments; M.B.V. and S.M.Z. analyzed the data; and S.M.Z. and M.B.V. wrote the paper while G.D.B. and E.D.N. provided constructive feedback.

Conflicts of Interest: The authors declare no conflict of interest.

\begin{tabular}{ll}
\multicolumn{2}{l}{ Abbreviations } \\
SOM & Soil organic matter \\
SOC & Soil organic carbon \\
MBC & Microbial biomass carbon \\
MBN & Microbial biomass nitrogen \\
CCC & Continuous corn \\
CS & Corn-soybean \\
CSW & Corn-soybean-wheat \\
SSS & Continuous soybean \\
NT & No-till \\
CT & Chisel tillage
\end{tabular}

\section{References}

1. Schimel, J.P.; Schaeffer, S.M. Microbial control over carbon cycling in soil. Front. Microbiol. 2012, 3, 1-11. [CrossRef] [PubMed]

2. Miltner, A.; Bombach, P.; Schmidt-Brücken, B.; Kästner, M. Som genesis: Microbial biomass as a significant source. Biogeochemistry 2012, 111, 41-55. [CrossRef]

3. Blanco-Canqui, H.; Lal, R. Mechanisms of carbon sequestration in soil aggregates. Crit. Rev. Plant Sci. 2004, 23, 481-504. [CrossRef]

4. Amézketa, E. Soil aggregate stability: A review. J Sustain. Agric. 1999, 14, 83-151. [CrossRef]

5. Needelman, B.A.; Wander, M.M.; Bollero, G.A.; Boast, C.W.; Sims, G.K.; Bullock, D.G. Interaction of tillage and soil texture biologically active soil organic matter in Illinois. Soil Sci. Soc. Am. J. 1999, 63, 1326-1334. [CrossRef]

6. Kumar, S.; Kadono, A.; Lal, R.; Dick, W. Long-term no-till impacts on organic carbon and properties of two contrasting soils and corn yields in Ohio. Soil Sci. Soc. Am. J. 2012, 76, 1798-1809. [CrossRef]

7. McDaniel, M.D.; Tiemann, L.K.; Grandy, A.S. Does agricultural crop diversity enhance soil microbial biomass and organic matter dynamics? A meta-analysis. Ecol. Appl. 2014, 24, 560-570. [CrossRef] [PubMed]

8. Stockmann, U.; Adams, M.A.; Crawford, J.W.; Field, D.J.; Henakaarchchi, N.; Jenkins, M.; Minasny, B.; McBratney, A.B.; De Remy de Courcelles, V.; Singh, K.; et al. The knowns, known unknowns and unknowns of sequestration of soil organic carbon. Agric. Ecosyst. Environ. 2013, 164, 80-99. [CrossRef]

9. West, T.O.; Post, W.M. Soil organic carbon sequestration rates by tillage and crop rotation: A global data analysis. Soil Sci. Soc. Am. J. 2002, 66, 1930-1946. [CrossRef]

10. Karlen, D.L.; Varvel, G.E.; Bullock, D.G.; Cruse, R.M. Crop rotations for the 21st century. Adv. Agron. 1994, $53,1-45$.

11. Divito, G.A.; Rozas, H.R.S.; Echeverría, H.E.; Studdert, G.A.; Wyngaard, N. Long term nitrogen fertilization: Soil property changes in an argentinean pampas soil under no tillage. Soil Tillage Res. 2011, 114, 117-126. [CrossRef]

12. Zuber, S.M.; Behnke, G.D.; Nafziger, E.D.; Villamil, M.B. Crop rotation and tillage effects on soil physical and chemical properties in Illinois. Agron. J. 2015, 107, 971-978. [CrossRef]

13. Johnson, A.M.; Hoyt, G.D. Changes to the soil environment under conservation tillage. HortTechnology 1999, 9, 380-393.

14. Martens, D.A. Nitrogen cycling under different soil management systems. Adv. Agron. 2001, 70, 143-192. 
15. Govaerts, B.; Mezzalama, M.; Unno, Y.; Sayre, K.D.; Luna-Guido, M.; Vanherck, K.; Dendooven, L.; Deckers, J. Influence of tillage, residue management, and crop rotation on soil microbial biomass and catabolic diversity. Appl. Soil Ecol. 2007, 37, 18-30. [CrossRef]

16. Zuber, S.M.; Villamil, M.B. Meta-analysis approach to assess effect of tillage on microbial biomass and enzyme activities. Soil Biol. Biochem. 2016, 97, 176-187. [CrossRef]

17. Balesdent, J.; Chenu, C.; Balabane, M. Relationship of soil organic matter dynamics to physical protection and tillage. Soil Tillage Res. 2000, 53, 215-230. [CrossRef]

18. Nannipieri, P.; Ascher, J.; Ceccherini, M.T.; Landi, L.; Pietramellara, G.; Renella, G. Microbial diversity and soil functions. Eur. J. Soil Sci. 2003, 54, 655-670. [CrossRef]

19. Soil Survey Staff Web Soil Survey. Available online: http://websoilsurvey.nrcs.usda.gov/ (accessed on 7 March 2018).

20. McGeehan, S.L.; Naylor, D.V. Automated instrumental analysis of carbon and nitrogen in plant and soil samples. Commun. Soil Sci. Plant Anal. 1988, 19, 493-505. [CrossRef]

21. Nelson, D.W.; Sommers, L.E. Total carbon, organic carbon, and organic matter. In Methods of Soil Analyses, Part 3, Chemical Methods; Sparks, D.L., Ed.; Soil Science Society of America: Madison, WI, USA, 1996; pp. 961-1010.

22. Rice, C.W.; Moorman, T.B.; Beare, M. Role of microbial biomass carbon and nitrogen in soil quality. In Methods for Assessing Soil Quality; Doran, J.W., Jones, A.J., Eds.; Soil Science Society of America: Madison, WI, USA, 1996; pp. 203-215.

23. Sparling, G.P.; West, A.W. Importance of soil water content when estimating soil microbial C, N and P by the fumigation-extraction methods. Soil Biol. Biochem. 1989, 21, 245-253. [CrossRef]

24. Littell, R.C.; Milliken, G.A.; Stroup, W.W.; Wolfinger, R.D.; Schabenberger, O. Sas for Mixed Models, 2nd ed.; SAS Institute, Inc.: Cary, NC, USA, 2006; p. 745.

25. Van Eerd, L.L.; Congreves, K.A.; Hayes, A.; Verhallen, A.; Hooker, D.C. Long-term tillage and crop rotation effects on soil quality, organic carbon, and total nitrogen. Can. J. Soil Sci. 2014, 94, 303-315. [CrossRef]

26. Ajwa, H.; Tabatabai, M. Decomposition of different organic materials in soils. Biol. Fertil. Soils 1994, 18, 175-182. [CrossRef]

27. Melillo, J.M.; Aber, J.D.; Linkins, A.E.; Ricca, A.; Fry, B.; Nadelhoffer, K.J. Carbon and nitrogen dynamics along the decay continuum: Plant litter to soil organic matter. In Ecology of Arable Land-Perspectives and Challenges, Proceedings of the International Symposium, Swedish University of Agricultural Sciences, Uppsala, Sweden, 9-12 June 1987; Clarholm, M., Bergström, L., Eds.; Springer: Dordrecht, The Netherlands, 1989; pp. 53-62.

28. Shahbaz, M.; Kuzyakov, Y.; Heitkamp, F. Decrease of soil organic matter stabilization with increasing inputs: Mechanisms and controls. Geoderma 2017, 304, 76-82. [CrossRef]

29. Xiao, C.; Guenet, B.; Zhou, Y.; Su, J.; Janssens, I.A. Priming of soil organic matter decomposition scales linearly with microbial biomass response to litter input in steppe vegetation. Oikos 2015, 124, 649-657. [CrossRef]

30. Moreno-Cornejo, J.; Zornoza, R.; Doane, T.A.; Faz, Á.; Horwath, W.R. Influence of cropping system management and crop residue addition on soil carbon turnover through the microbial biomass. Biol. Fertil. Soils 2015, 51, 839-845. [CrossRef]

31. Havlin, J.L.; Kissel, D.E.; Maddux, L.D.; Claassen, M.M.; Long, J.H. Crop rotation and tillage effects on soil organic carbon and nitrogen. Soil Sci. Soc. Am. J. 1990, 54, 448-452. [CrossRef]

32. Varvel, G.E. Rotation and nitrogen fertilization effects on changes in soil carbon and nitrogen. Agron. J. 1994, 86, 319-325. [CrossRef]

33. Ciampitti, I.A.; Vyn, T.J. Physiological perspectives of changes over time in maize yield dependency on nitrogen uptake and associated nitrogen efficiencies: A review. Field Crops Res. 2012, 133, 48-67. [CrossRef]

34. Delogu, G.; Cattivelli, L.; Pecchioni, N.; De Falcis, D.; Maggiore, T.; Stanca, A.M. Uptake and agronomic efficiency of nitrogen in winter barley and winter wheat. Eur. J. Agron. 1998, 9, 11-20. [CrossRef]

35. Gentry, L.E.; Below, F.E.; David, M.B.; Bergerou, J.A. Source of the soybean N credit in maize production. Plant Soil 2001, 236, 175-184. [CrossRef]

36. Salvagiotti, F.; Cassman, K.G.; Specht, J.E.; Walters, D.T.; Weiss, A.; Dobermann, A. Nitrogen uptake, fixation and response to fertilizer $\mathrm{n}$ in soybeans: A review. Field Crops Res. 2008, 108, 1-13. [CrossRef] 
37. Varvel, G.E.; Wilhelm, W.W. No-tillage increases soil profile carbon and nitrogen under long-term rainfed cropping systems. Soil Tillage Res. 2011, 114, 28-36. [CrossRef]

38. Franzluebbers, A.J.; Hons, F.M. Soil-profile distribution of primary and secondary plant-available nutrients under conventional and no tillage. Soil Tillage Res. 1996, 39, 229-239. [CrossRef]

39. Chabbi, A.; Rumpel, C. Organic matter dynamics in agro-ecosystems-The knowledge gaps. Eur. J. Soil Sci. 2009, 60, 153-157. [CrossRef]

40. Fontaine, S.; Barot, S. Size and functional diversity of microbe populations control plant persistence and long-term soil carbon accumulation. Ecol. Lett. 2005, 8, 1075-1087. [CrossRef]

41. Russell, A.E.; Laird, D.A.; Mallarino, A.P. Nitrogen fertilization and cropping system impacts on soil quality in midwestern mollisols. Soil Sci. Soc. Am. J. 2006, 70, 249-255. [CrossRef]

42. Ekenler, M.; Tabatabai, M. B-glucosaminidase activity of soils: Effect of cropping systems and its relationship to nitrogen mineralization. Biol. Fertil. Soils 2002, 36, 367-376. [CrossRef]

43. Bonkowski, M. Protozoa and plant growth: The microbial loop in soil revisited. New Phytol. 2004, 162, 617-631. [CrossRef]

44. Nannipieri, P.; Eldor, P. The chemical and functional characterization of soil $\mathrm{N}$ and its biotic components. Soil Biol. Biochem. 2009, 41, 2357-2369. [CrossRef]

45. Schimel, J.P.; Bennett, J. Nitrogen mineralization: Challenges of a changing paradigm. Ecology 2004, 85, 591-602. [CrossRef]

46. Carter, M.R.; Gregorich, E.G.; Angers, D.A.; Beare, M.H.; Sparling, G.P.; Wardle, D.A.; Voroney, R.P. Interpretation of microbial biomass measurements for soil quality assessment in humid temperate regions. Can. J. Soil Sci. 1999, 79, 507-520. [CrossRef]

(C) 2018 by the authors. Licensee MDPI, Basel, Switzerland. This article is an open access article distributed under the terms and conditions of the Creative Commons Attribution (CC BY) license (http://creativecommons.org/licenses/by/4.0/). 